ОРИГИНАЛЬНЫЕ СТАТЬИ / ORIGINAL PAPERS

DOI: 10.17073/2500-0632-2019-3-181-187

\title{
Behaviour of Pollutants in the Upper Reaches of East Jiu River Case Study
}

\author{
A. F. Simion ${ }^{1}$, M. Lazar ${ }^{2}$, C. Drebenstedt ${ }^{3}$
}

${ }^{1}$ National Institute for Research and Development in Mine Safety and Protection to ExplosionINSEMEX Petroşani, Romania

${ }^{2}$ University of Petrosani, Petrosani, Romania

${ }^{3}$ Technische Universität Berg Akademie Freiberg, Freiberg, Germany

\begin{abstract}
Surface water pollution is one of the consequences of modern society development through permanent pressures on the environment imposed by economic activities to provide the necessary resources for keeping modern living standards. Degradation of fresh water bodies is caused by the disappearance of natural water collection areas, deforestation and unsustainable farming practices, river pollution with wastes and the discharge of nontreated domestic and industrial wastewater into natural recipients. The main purpose of the mathematical modeling of rivers is to predict pollution dispersal in longitudinal and transversal directions, taking into account water body mixing coefficient. This paper is devoted to monitoring of physico-chemical indicators in the sampled river reaches and simulation of pollutant dispersal in the upper reaches of the East Jiu river.
\end{abstract}

Keywords: surface water pollution, environment, flow dynamics computation, mining, water.

For citation: Simion A. F., Lazar M., Drebenstedt C. Behaviour of pollutants in the upper reaches of East Jiu River case study. Mining Science and Technology. 2019;4(3):181-187. DOI: 10.17073/2500-0632-2019-3181-187.

\section{Анализ распространения загрязняющих веществ на примере верховьев р. Ист Джиу \\ Симион А. Ф. ${ }^{1}$, Лазар М. ${ }^{2}$, Дребенштедт К. ${ }^{3}$}

${ }^{1}$ National Institute for Research and Development in Mine Safety and Protection to ExplosionINSEMEX, Петрошани, Румыния

${ }^{2}$ University of Petrosani, Петрошани, Румыния

${ }^{3}$ Фрайбергская горная академия, Фрайберг, Германия

Аннотация: Загрязнение поверхностных вод является одним из последствий развития современного общества и экономической деятельности на основе эксплуатации природных ресурсов с оказанием постоянного давления на окружающую среду - в целях поддержания высокого уровня жизни здесь и сейчас. Деградация пресноводных водоемов вызвана исчезновением природных водосборных площадей, вырубкой лесов и истощающими природные ресурсы и экологически опасными методами ведения сельского хозяйства, загрязнением рек мусором и сбросом бытовых и промышленных сточных вод в природные водоемы без надлежащей очистки. Основной целью математического моделирования рек является прогнозирование распространения загрязняющего вещества в продольном и поперечном направлении с учетом коэффициента перемешивания вод водоема. Эта статья посвящена мониторингу физико-химических показателей вод на участках отбора проб воды, а также моделированию рассеяния загрязняющих веществ в верхнем течении реки Ист Джиу.

Ключевые слова: загрязнение вод, окружающая среда, расчет динамики водных потоков, горные работы, воды.

Для цитирования: Симион А. Ф., Лазар М., Дребенштедт К. Анализ распространения загрязняющих веществ на примере верховьев р. Ист Джиу. Горные науки и технологии. 2019;4(3):181-187. DOI: 10.17073/2500-0632-2019-3-181-187. 


\section{Introduction}

Study of water streams involves continuous modeling of material behavior at macroscopic level, in the form of the study of fluids in terms of steady state and fluctuation (dynamics), as well as investigating interactions between fluids and solid surfaces. These complex phenomena are studied mainly by fluid mechanics, which is based on the principles of classical physics (mechanics) [5]. Fluid mechanics approach in natural conditions is, however, complicated by the fact that in most cases the flow is turbulent, which implies high degree of complexity [5]. Importance of the question under consideration is connected with limited global reserves of freshwater and their contamination caused by anthropogenic activities. From qualitative, water has a microbiological and a physico-chemical components, which permanently interact with aquatic ecosystems. The paper objectives are to monitor water quality parameters in the sampled areas/sections and study the time-dependent and spatial evolution of pollutant concentrations in the upper reaches of East Jiu River. Possible sources of pollution in the studied area are mining, waste disposal, agriculture, and wood processing, and the components to be monitored are heavy metals, anions, cations, $\mathrm{pH}$, phenols, total phosphorus and suspended solids [1, 2, 4].

\section{Methodology of the river pollutant behavior simulation}

The simulation of pollutant behaviour in water courses using specialized software requires thorough study of the investigated area in terms of monitoring of hydrodynamic regime and physico-chemical parameters of the water $[3,5]$.

Simulation of pollutant dispersion in surface water requires prior determining river bed geometry, followed by equation meshing and setting the boundary conditions. For this simulation of the pollutant dispersion, the Surface Water Modeling System (SWMS) software was used, which involves two steps:

1. The first step included modeling the sector dynamics using RMA2 module with topogra- phy and river bathymetry, as well as dynamic elements, as input data.

2. The second step covered modeling the pollutant concentration field evolution (pollutant dispersion) using RMA4 module with the first step RMA2 module data as input data.

The Navier-Stokes equation system in the Reynolds form for the Cartesian coordinates $\mathrm{x}$ and $y$ is used to simulate dynamic water flow elements together with the continuity equation for free-flowing incompressible fluids in conditions of turbulent motion:

- Navier-Stokes equations (Eq.1, 2):

$$
\begin{gathered}
h \frac{\partial u}{\partial t}+h u \frac{\partial u}{\partial x}+h v \frac{\partial u}{\partial y}-\frac{h}{\rho}\left(E_{x x} \frac{\partial^{2} u}{\partial x^{2}}+E_{x y} \frac{\partial^{2} u}{\partial y^{2}}\right)+ \\
+g h\left(\frac{\partial H}{\partial x}+\frac{\partial h}{\partial x}\right)+\frac{g u n^{2}}{\left(h^{1 / 6}\right)^{2}} \times \\
\times\left(u^{2}+v^{2}\right)^{1 / 2}-\varsigma V_{a}^{2} \sin \psi+2 h \omega v \sin \varphi=0, \quad(1) \\
\frac{\partial h}{\partial t}+h\left(\frac{\partial u}{\partial x}+E_{x y} \frac{\partial v}{\partial y}\right)+u \frac{\partial h}{\partial x}+v \frac{\partial h}{\partial y}=0 ;(2)
\end{gathered}
$$

- the continuity equation (Eq.3):

$$
\begin{gathered}
h \frac{\partial v}{\partial t}+h u \frac{\partial v}{\partial x}+h v \frac{\partial v}{\partial y}-\frac{h}{\rho}\left(E_{y x} \frac{\partial^{2} v}{\partial x^{2}}+E_{y y} \frac{\partial^{2} v}{\partial y^{2}}\right)+ \\
+g h\left(\frac{\partial H}{\partial y}+\frac{\partial h}{\partial y}\right)+\frac{g v n^{2}}{\left(h^{1 / 6}\right)^{2}} \times \\
\times\left(u^{2}+v^{2}\right)^{1 / 2}-\varsigma V_{a}^{2} \sin \omega+2 h \omega v \sin \varphi=0
\end{gathered}
$$

where:

$h$ - water depth (m);

$u$ - local velocity in $\mathrm{x}$ direction $(\mathrm{m} / \mathrm{s})$;

$v$ - local velocity in y direction $(\mathrm{m} / \mathrm{s})$;

$t$ - time (s);

$\rho$ - water density $\left(\mathrm{kg} / \mathrm{m}^{3}\right)$;

$g-$ gravitational acceleration $\left(\mathrm{m} / \mathrm{s}^{2}\right)$;

$E$ - coefficients of turbulent viscosity (Pa.s or $\mathrm{kg} / \mathrm{m} / \mathrm{s}$ ), which is calculated automatically using Peclet number: $P e=\frac{\rho U d x}{E}$, in which 
$U=\sqrt{u^{2}+v^{2}}$ is average resultant speed, and $d x-$ length element in the direction of flow;

$H$ - elevation of the river bed (m);

$n$ - Manning coefficient of roughness;

$\varsigma$-empirical coefficient of air friction;

$V_{a}-$ wind velocity $(\mathrm{m} / \mathrm{s})$;

$\psi$ - wind direction (degrees in the inverse direction from the positive axis $x$ );

$\omega$ - angular rotation speed of the Earth $(\mathrm{rad} / \mathrm{s})$;

$\varphi$ - location latitude [6].

Fundamental equation of advectiondispersion (Eq. 4) is used for determining evolution of pollutant concentration field:

$$
\begin{aligned}
& h\left(\frac{\partial c}{\partial t}+u \frac{\partial c}{\partial x}+v \frac{\partial c}{\partial y}-\frac{\partial}{\partial x} D x \frac{\partial c}{\partial x}-\right. \\
& \left.-\frac{\partial}{\partial y} D y \frac{\partial c}{\partial y}-\sigma-k c+\frac{R(c)}{h}\right)=0,
\end{aligned}
$$

where:

$c$ - pollutant concentration $\left(\mathrm{mg} / \mathrm{dm}^{3}\right)$;

$D x$ and $D y-$ coefficients of turbulent diffusion in $x$ and $y$ direction;

$k$ - permanent degradation (s-1);

$\sigma-$ local pollutant source (concentration measure unit);

$h$ - water depth (m); (c) - precipitation/evaporation (concentration measure unit, $\mathrm{m} / \mathrm{s}$ ).

The first term in the equation signifies local variation of concentration; the second term is the advective term in $x$ direction; the third term is the advective term in $y$ direction; the fourth is the term of dispersion in $x$ direction; the fifth is the term of dispersion in $y$ direction; the sixth term means the local pollutant source; the seventh term shapes the pollutant exponential ; and eighth term reflects the effect of precipitation/evaporation [7].

The SWMS RMA2 module was used under the assumption of hydrostatic pressure; the accelerations in vertical direction are negligible. It is two-dimensional in horizontal plane. It is not intended to be used for near field problems where vortices, vibrations, or vertical accelerations are of primary interest. Vertically stratified flow effects are beyond the capabilities of RMA2 [6].

3. Simulation of pollutants in upper reaches of East Jiul River

The reach covered by the study of pollutant dispersal is represented by the confluence of Taia River with East Jiu River, approximately $1.2 \mathrm{~km}$ long with the river bed elevation difference of $7 \mathrm{~m}$ (Fig.1).

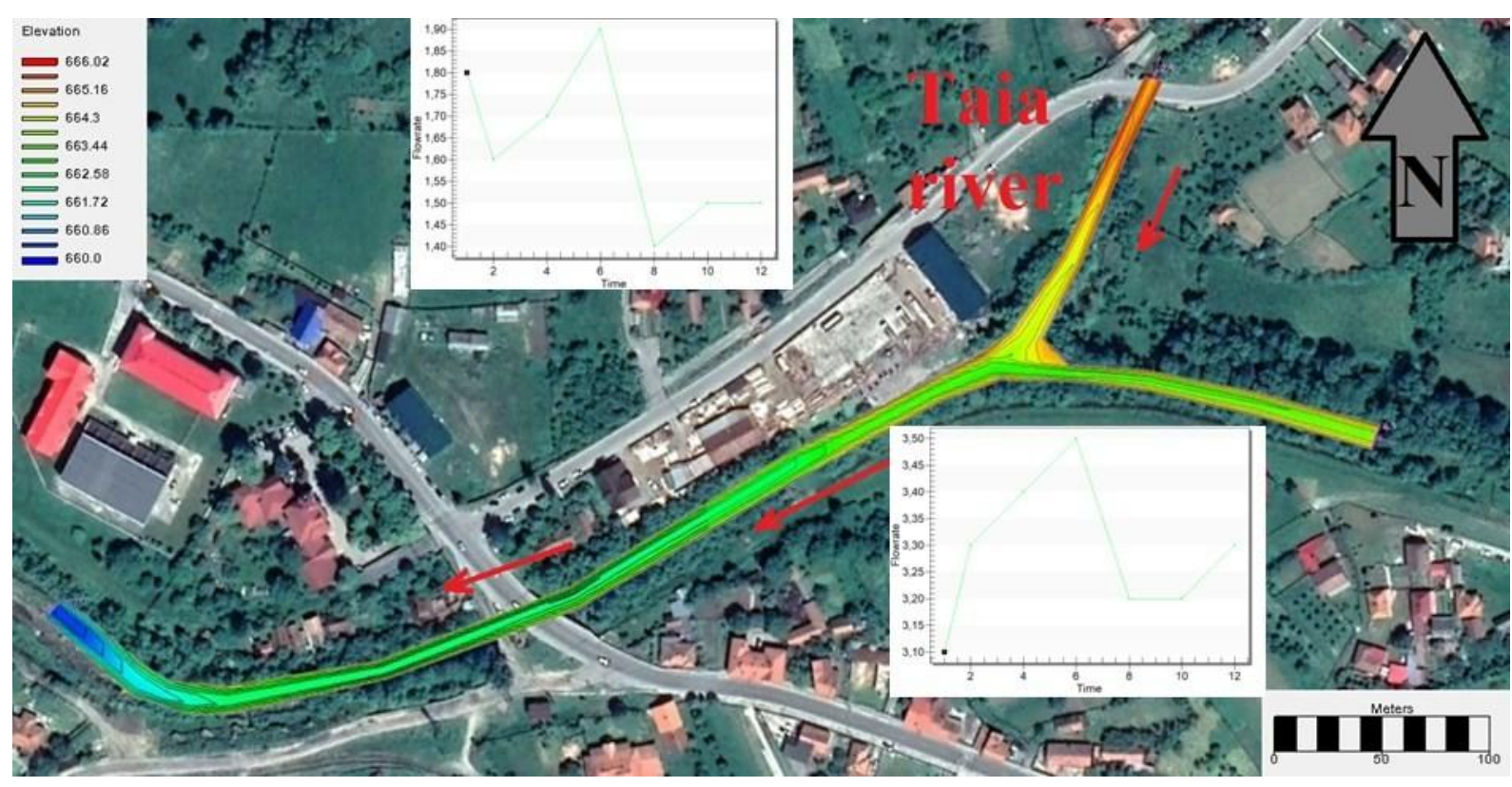

Fig. 1. Elevation of the river bed 
Table 1

Domain dynamics elements

\begin{tabular}{|l|c|c|c|c|c|c|c|}
\hline \multirow{2}{*}{ Boundary condition } & \multicolumn{7}{|c|}{ Time (h) } \\
\cline { 2 - 8 } & $\mathbf{1}$ & $\mathbf{2}$ & $\mathbf{4}$ & $\mathbf{6}$ & $\mathbf{8}$ & $\mathbf{1 0}$ & $\mathbf{1 2}$ \\
\hline Water temperature $\left({ }^{\circ} \mathrm{C}\right)$ & \multicolumn{7}{|c|}{ Taia river } \\
\hline Density $\left(\mathrm{kg} / \mathrm{m}^{3}\right)$ & \multicolumn{7}{|c|}{999} \\
\hline & \multicolumn{7}{|c|}{ East Jiu river } \\
\hline Flow rate $\left(\mathrm{m}^{3} / \mathrm{s}\right)$ & 1.8 & 1.6 & 1.9 & 1.4 & 1.5 & 1.5 \\
\hline
\end{tabular}

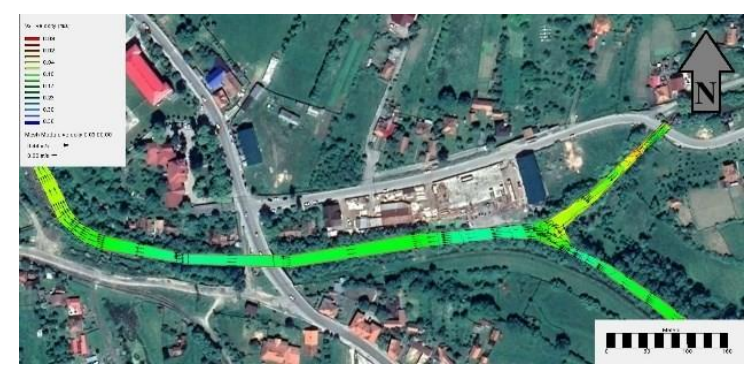

Fig. 2. Field of velocity in $V_{x}$ direction

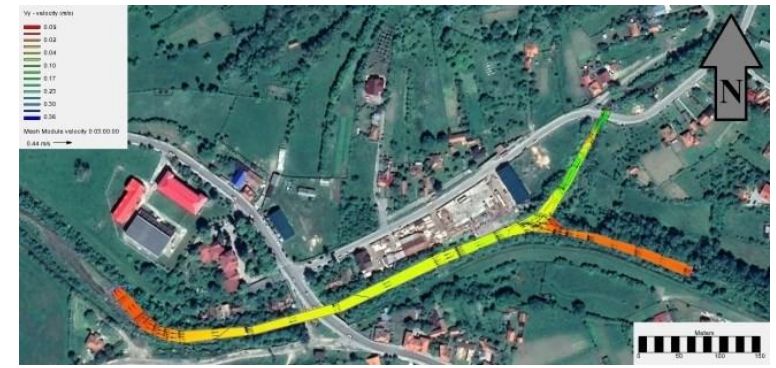

Fig. 3. Field of velocity in $V_{y}$ direction

Table 2

Physical and chemical analyzes of water samples in the river reaches

\begin{tabular}{|c|c|c|c|}
\hline Indicator $\quad$ Sampling point & Raul jiu Amont Taia & Râul taia amonte & Jiet amonte \\
\hline Temperature, ${ }^{\circ} \mathrm{C}$ & 8.1 & 7.8 & 5.9 \\
\hline $\mathrm{pH}$ & 6.7 & 7.41 & 7.08 \\
\hline Conductivity, $\mu \mathrm{S} / \mathrm{m}^{2}$ & 145.6 & 138.5 & 159.4 \\
\hline TDS*, mg/l & 83.9 & 88.9 & 92.7 \\
\hline Turbidity, NTU & 46.5 & 45.7 & 9 \\
\hline Sodium, mg/l & 15.1 & 14.5 & 15.8 \\
\hline Dissolved $\mathrm{O}_{2}, \mathrm{mg} \mathrm{O}_{2} / 1$ & 11.91 & 12.23 & 14.81 \\
\hline $\mathrm{BOD}_{5}, \mathrm{mg} / \mathrm{l}$ & 6.34 & 6.24 & 3,46 \\
\hline Total phosphorus, mg/l & 0.14 & 0.10 & traces \\
\hline Nitrite $\mathrm{NO}_{2}^{-}, \mathrm{mg} / \mathrm{l}$ & 0.11 & 0.16 & 0.01 \\
\hline Nitrate $\mathrm{NO}_{3}^{-}, \mathrm{mg} / \mathrm{l}$ & 3.14 & 2.34 & 0.84 \\
\hline Sulphațe, mg/l & 68.9 & 62.4 & 21.5 \\
\hline Phenols, $\mu \mathrm{g} / \mathrm{l}$ & 0.8 & 1.12 & traces \\
\hline Arsenic, $\mu \mathrm{g} / \mathrm{l}$ & 14 & 17 & 3 \\
\hline Chromium, $\mu \mathrm{g} / \mathrm{l}$ & 3 & 4 & traces \\
\hline Copper, $\mu \mathrm{g} / \mathrm{l}$ & 5 & 6 & 2 \\
\hline Lead, $\mu \mathrm{g} / \mathrm{l}$ & traces & traces & 5 \\
\hline Mercury, $\mu \mathrm{g} / \mathrm{l}$ & traces & traces & traces \\
\hline
\end{tabular}

The computational domain for the two water courses was divided into 3 sub-domains, the left bank, the right bank, and the main river bed, because the study of pollutant dispersal (based on measuring pollutant concentrations) provides for both longitudinal analysis of the dispersal and the dispersal in the direction transverse to the flow analysis, especially in conditions of me- andering course. Field observations provided data on the flow dynamics in the modeled sector (Table 1) required to estimate accurate flow velocities in the three sub-domains.

For the simulation, the following conditions were taken into account as the model restrictions: Coriolis force, precipitation and evaporation ratio, wind regime, and Manning coeffi- 
cient of roughness calculated based on the bed structure (from 0.010 for boulder bed to 0.030 for vegetation bed).

\subsection{Simulation of dynamic elements}

Numerical simulation using the RMA2 application was performed over a 12-hour period to determine the velocity fields in $\mathrm{x}$-direction (Fig. 2) and y-direction (Fig. 3).

The analysis of the two velocity fields showed that the maximum velocity of the particles motion is $0.36 \mathrm{~m} / \mathrm{s}$ in $\mathrm{x}$ direction and 0.17 $\mathrm{m} / \mathrm{s}$ in $y$ direction. To verify the stability of the RMA2 numerical modeling, the Froude number was used.

\subsection{Simulation of pollutants dispersal}

The modeling of the concentrations in the river reaches involved water samples collected in three sampling points (Table 2) as follows: a blank sample taken upstream of the East Jiu river

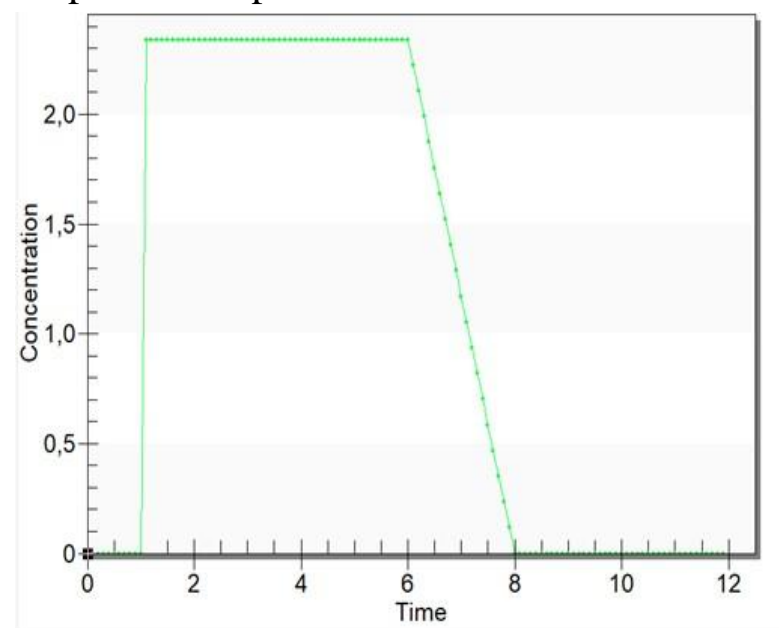

Fig. 4. Nitrate concentration trend

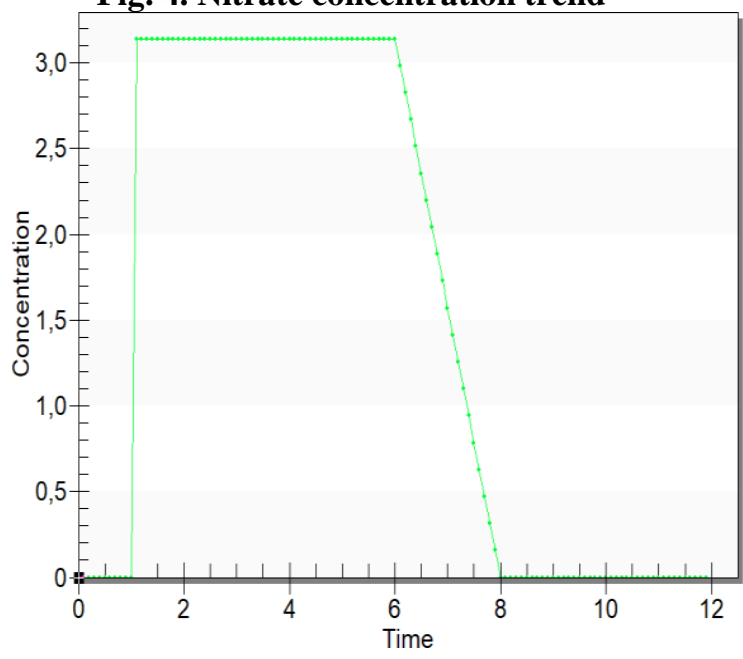

Fig. 6. Nitrate concentration trend basin to determine the background concentration and two samples taken in the upper boundary of the computation domain (Fig. 1).

The pollutant dispersal modeling was performed for the physico-chemical parameters classified in the lower quality classes according to the Norm 161 of February 16, 2006. Thus, sulfate and nitrate were concentrations studied, for which constant background concentration of $21.5 \mathrm{mg} / \mathrm{l}$ and $0.84 \mathrm{mg} / \mathrm{l}$, respectively, was established for the 12-hour simulation period.

For the reach of Taia River the following behaviour was determined: in one hour after the reach simulation start, maximum nitrate and sulfate pollution concentrations are achieved (Fig. 4) and (Fig. 5), respectively, and then they drops and since the $7^{\text {th }}$ hour for the rest of the 12-hour period returns to the background concentrations.

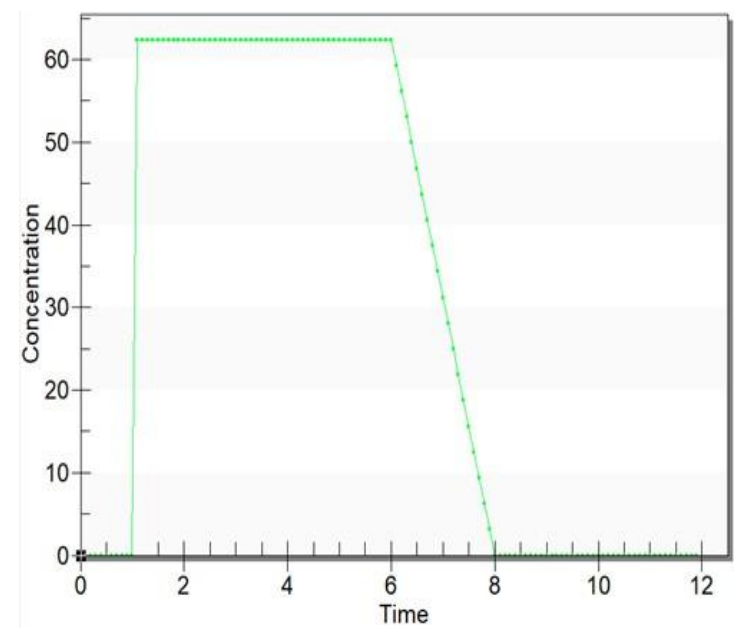

Fig. 5. Sulphate concentration trend

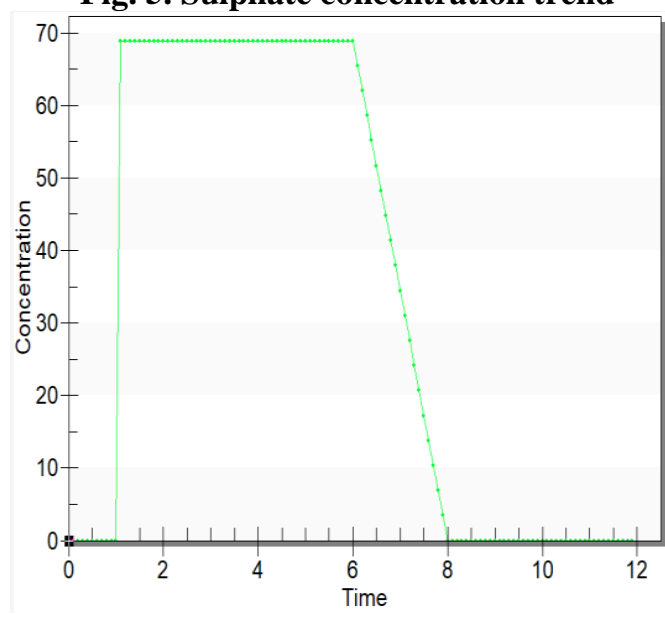

Fig. 7. Sulphate concentration trend 
Fig.8: Concentration of nitrate in 2 hours
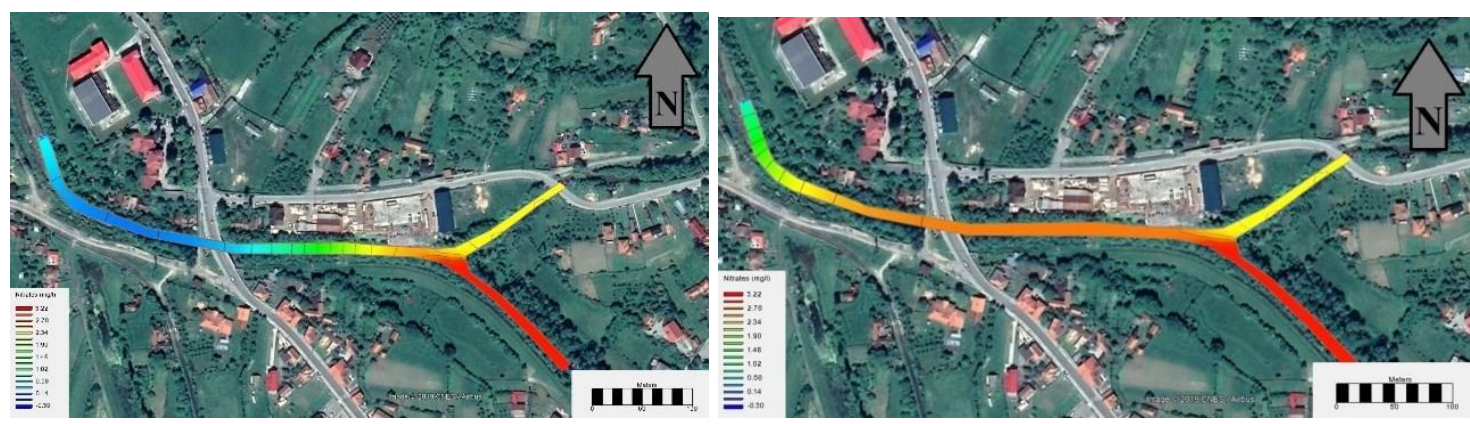

Fig.9: Concentration of nitrate in 3 hours

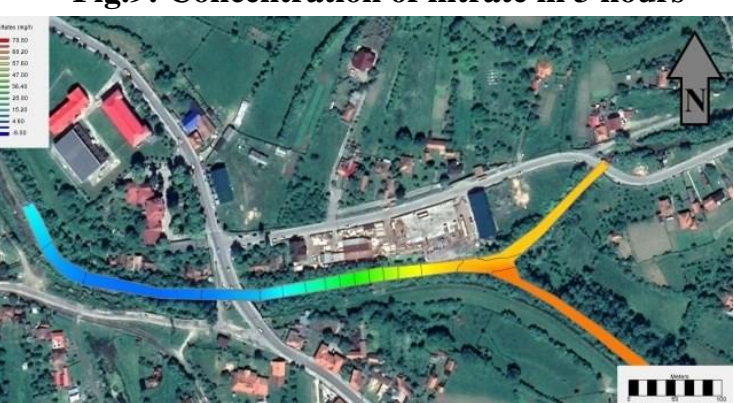

Fig.11: Concentration of sulphate in 2 hours

Fig. 10: Concentration of nitrate in 8 hours

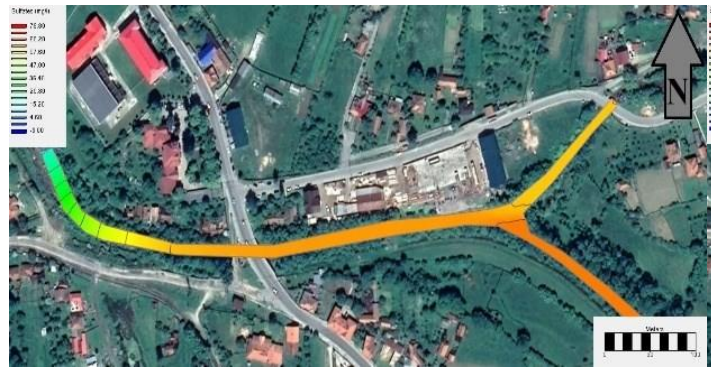

Fig.12: Concentration of sulphate in 3 hours

The dispersal maps for the nitrate and sulphate indicators have been prepared for the moments of 2, 3 and 8 hours after starting the simulation (Fig. 8 to Fig. 13) to demonstrate the evolution of the pollutant in the aquatic environment both at the modeled field entry and exit.

Calibration of the mathematical model was performed based on the concentrations obtained by direct laboratory measurements (Table 2) and the values obtained from the computerized simulation with variation of the Peclet number within the acceptable limits (15-40).

Similar behavior was determined for the East Jiu River reach: in one hour after the reach simulation start, maximum nitrate and sulfate pollution concentrations are achieved (Fig. 6) and (Fig. 7), respectively, and then they drops and since the $7^{\text {th }}$ hour for the rest of the 12-hour period returns to the background concentrations.

\section{Discussion}

The studied river reach is located in an anthropized area, which can be influenced by

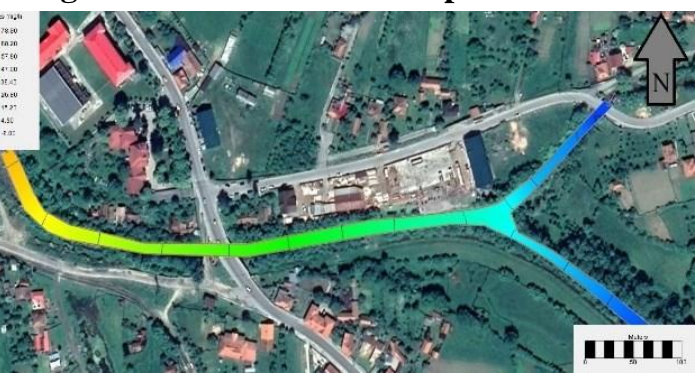

Fig.13: Concentration of sulphate in 8 hours

local mining (Lonea mine), agriculture, animal husbandry, woodworking, road traffic. Pollutants generated by these economic activities achieve the natural surface water bodies through different mechanisms and ways and once they reach the water bodies they produce significant impact on the aquatic and terrestrial ecosystems. In the impacted water reaches the pollutants concentrations in water depend mainly on: water flow rate, the material composing the riverbed, the terrain and regional climate.

The computerized simulations show that the nitrate concentration is reduced by half in the East Jiu River.

In the studied area, increasing the concentration of pollutants on the watercourse banks is determined, which increases the risk of degradation of the riparian ecosystems. The pollutants ingested by living organisms are transferred along the food chain, producing unfavorable impacts on the ecosystems. 


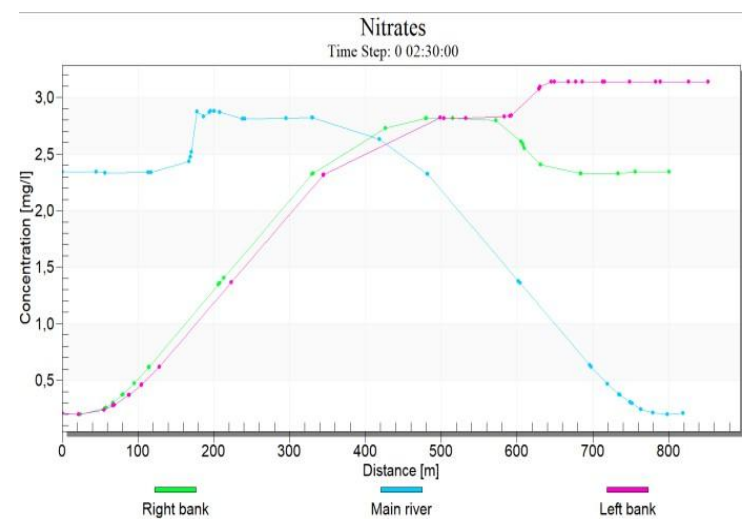

Fig. 14: Dispersal of nitrate concentration in 2 hours

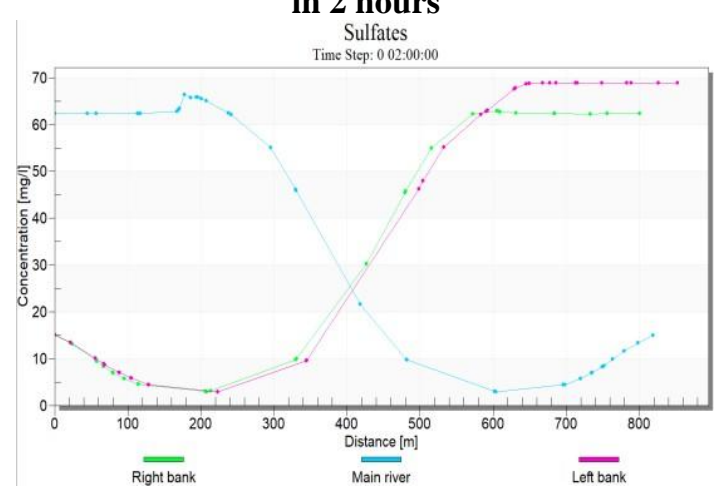

Fig. 16: Dispersal of sulfate concentration in 2 hours

\section{Conclusions}

From view point of environmental pollution estimation, the use of Computational Fluid Dynamics modeling tools to determine the pollution dispersal and impact on water bodies is quite effective as it is a tool allowing to view data across the studied field based on minimal number of rather expensive water assays and, thus, save money and time.

Advection processes predominate in the East Jiu river basin, and, in the main course of the river, dispersal processes prevail, mainly due

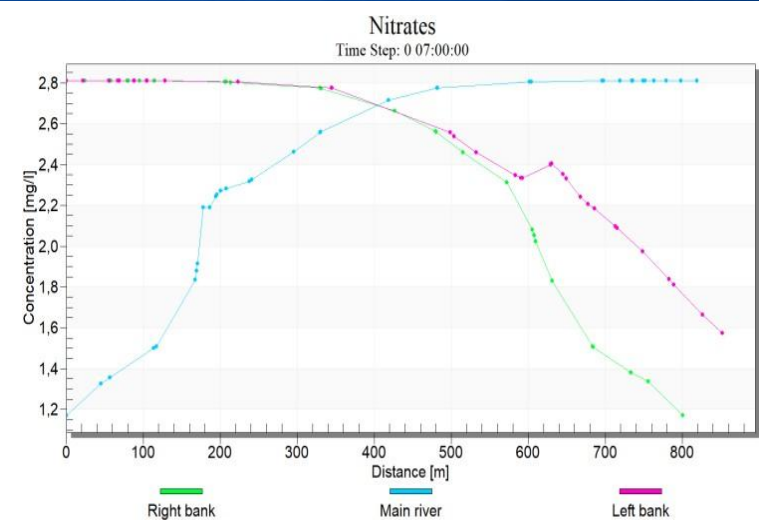

Fig. 15: Dispersal of nitrate concentration in 7 hours

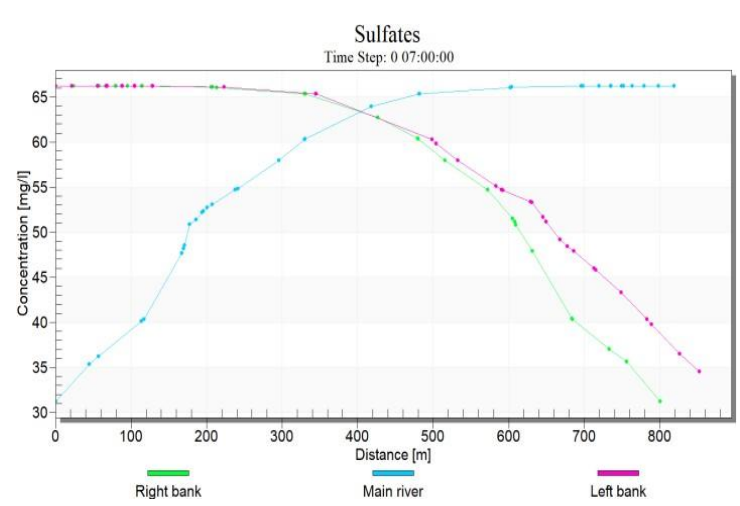

Fig. 17: Dispersal of sulfate concentration in 7 hours

to the riverbed material, and watercourse and local turbulence. In terms of pollutant dispersal, there is a close link between the water flow rate and the amount of pollutant getting into the aquatic environment. Dilution of pollutants in the aquatic environment may take place in terms of decreasing pollutant concentrations, but additional amounts of pollutants contributed by various tributaries from the southern and eastern parts of the area lead to increasing pollution downstream in the river basin.

\section{References} 2006.

1. Lazar M., Dumitrescu I., Anthropic impact on the environment, Universitas Publishing House, Romania,

2. Lazar M., The rehabilitation of the degraded lands, Universitas Publishing House, Romania, 2010.

3. Mitroiu C., Marin., Ingineria Râurilor - Regularizareaalbiilorrâurilorșiîndiguiri, Bren Publishing House, Romania, 1999.

4. Rotunjanu I., Lazăr M. Hydrology and mining hydrogeology minieră. Universitas Publishing House, Petroşani, Romania, 2014.

5. Stephen B. P. Turbulent Flows, Cambridge university press.

6.Surface Water Modeling System - RMA2. US Army Engineer Research and Development Center, AquaVeo, USA, 2011.

7. Surface Water Modeling System - RMA4. US Army Engineer Research and Development Center, AquaVeo, USA, 2011. 